\title{
Optimization of blue berry extraction for beverage production using enzyme treatment
}

\author{
$\mathrm{Yu}$-Jeong Ji, Moo-Hyeog Im* \\ Department of Food Engineering, Daegu University, Gyeongsan 38453, Korea
}

\section{효소처리에 의한 블루베리 음료 생산을 위한 최적추출조건}

\author{
지유정 · 임무혁* \\ 대구대학교 식품공학과
}

\begin{abstract}
In this study, we tried to establish the best method for fresh bluebery beverage production using enzyme treatment as well as low temperature extraction. During extraction of physiologically functional materials, we used low temperature to prevent nutritional loss by heat. In addition, we investigated optimal blueberry extraction conditions using various enzyme treatments (cellulase, pectinase, cellulase:pectinase (1:1) mixture) to increase extraction efficiency and reduce turbidity. A variety and ratio of enzymes, extraction temperature, extraction time, and shaking speed were considered for the best extraction efficiency rate. We observed high extraction efficiency rates of $85.72-86.55 \%$ and 87.06-87.93\%, respectively, upon cellulase or pectinase treatment. In addition, a mixture of cellulase:pectinase (1:1) showed an extraction efficiency rate of 86.84-88.14\%. The best extraction efficiency rate was observed when crude bluebeny was treated at $45^{\circ} \mathrm{C}(87.91 \%)$, for $3 \mathrm{~h}(87.88 \%)$, in a $90 \mathrm{rpm}$ shaker $(89.19 \%)$. Sugar content and acidity of blueberry extract were not affected by the various treatments. However, total phenolic compounds were detected upon pectinase treatment $(18.62 \mathrm{mg} / \mathrm{g})$. Only fructose and glucose as free sugars were found in all samples regardless of treatments and extraction conditions.
\end{abstract}

Key words : blueberry, blueberry extraction, blueberry beverage, cellulase, pectinase

\section{서 론}

최근 건강에 대한 관심이 증대됨에 따라 다양한 영양분 의 섭취와 질병 예방에 효과가 있는 각종 과실에 대한 연구 및 이를 이용한 제품 개발 연구가 활발히 진행되고 있다. 천연 항산화 물질에 관한 연구에 따르면 여러 과일 중에서 도 블루베리를 비롯한 아사이 베리, 블랙베리 등 각종 베리 류 들의 항산화 활성이 높았다는 보고가 있으며(1-3), 그 중 블루베리는 여러 가지 뛰어난 생체 조절 기능이 있어 성인병을 예방하고 치유하는 기능이 보고되었다. 블루베리

*Corresponding author. E-mail : imh0119@daegu.ac.kr Phone : 82-53-850-6537, Fax : 82-53-850-6539

Received 12 October 2016; Revised 16 January 2017; Accepted 18 January 2017.

Copyright (c) The Korean Society of Food Preservation. All rights reserved.
는 진달래과(Ericaceae) 산앵두나무 속(Vaccinium)에 속하 는 관목성 식물로서 400여 종이 있으며(4) 열매는 둥글고 성숙에 따라 과색이 변하고 표면에 왁스 층이 증가하는 특징이 있다(5). 현재 블루베리를 이용하여 요구르트(6), 포도주(7), 젤리(8), 쿠키(9) 등의 식품으로 가공한 연구가 보고되고 있으며 새로운 제품 개발 연구가 활발히 진행되고 있다.

최근 국내 음료 시장은 건강에 대한 소비자들의 관심이 높아짐에 따라 수요가 급증함과 동시에 더욱 고급화되고 다양화 되는 경향을 보인다. 우리나라 식품공전 상 음료류 는 과일·채소류음료, 인삼·홍삼음료, 두유류, 탄산음료류, 발효음료류 및 기타음료 등 음용을 목적으로 하는 식품을 말하며 특히 과일·채소음료는 농축 즙, 주스, 음료의 3 가지 식품유형이 있다(10). 국내 과일·채소음료는 대부분은 과일 농축액을 이용한 환원형 음료가 유통되고 있으며 대표적으 로 참외(11), 매실(12), 오미자(13) 복분자(14) 등의 과일류 
와 둥근마(15), 잎새버섯(16), 쑥(17) 등의 채소류, 그리고 대추식초(18)와 같은 발효 음료 등 다양한 연구가 지속적으 로 이루어지고 있다. 그러나 환원형이 아닌 생과형 과일음 료의 연구에 관한 연구는 미비하다.

이에 본 연구에서는 생과형 블루베리 과일음료 생산을 위해 저온 추출공법을 사용하여 고온에서 생리활성 물질 추출 시 일어나는 영양분 손실을 막고 cellulase 및 pectinase 효소처리를 하여 혼탁 방지 및 수율 증가를 위한 최적의 추출조건을 확립하고자 한다. 또한, 연구를 진행함으로써 앞으로 효소처리에 의해 생산된 블루베리 추출액을 음료에 첨가하여 생과형 블루베리 음료 생산 체계를 확립하고 국내 생과형 과일음료 시장에 기초자료를 제공하고자 한다.

\section{재료 및 방법}

\section{실험재료}

본 실험에 사용된 블루베리는 경상북도 고령군 소재 농 장에서 2014년 수확한 것을 구입하여 사용하였다. 구입한 블루베리를 $-18^{\circ} \mathrm{C}$ 에 냉동 보관하면서 분석 시료로 사용하 였고, 실험 직전에 동결된 블루베리를 각 처리구별 $1 \mathrm{~kg}$ 씩 실온에서 해동시킨 후 블렌더(blender)로 파쇄 후 실험에 사용하였다. 효소는 cellulase $\left(27,000 \mathrm{U} / \mathrm{g}\right.$, Rohament ${ }^{\circledR C L}$, AB Enzymes, Rajamäki, Finaland)와 pectinase $(24,000 \mathrm{U} / \mathrm{g}$, Rohapect $囚 10 \mathrm{~L}, \mathrm{AB}$ Enzymes)를 구입하여 사용하였다.

\section{블루베리추출 조건}

효소의 종류 및 첨가량별 블루베리의 최적 추출조건을 확립하기 위하여 파쇄 된 블루베리 $100 \mathrm{~g}$ 에 증류수 900 $\mathrm{mL}$ 로 혼합한 후 효소를 처리를 하였다. 효소는 cellulase 처리구 $(0.05 \%=67.5 \mathrm{U}, 0.10 \%=270 \mathrm{U}, 0.15 \%=607.5 \mathrm{U} 0.20 \%$ $=1,080 \mathrm{U})$, pectinase 처리구 $(0.05 \%=60 \mathrm{U}, 0.10 \%=240 \mathrm{U}$, $0.15 \%=540 \mathrm{U}, 0.20 \%=960 \mathrm{U})$, cellulase:pectinase를 $1: 1(\mathrm{w} / \mathrm{v})$ 비율로 혼합하여 첨가한 처리구 $0.05 \%=63.75 \mathrm{U}, 0.10 \%=255$ $\mathrm{U}, 0.15 \%=573.75 \mathrm{U}, 0.20 \%=1,020 \mathrm{U}$ )를 사용하였다. 각각의 효소 처리구는 $45^{\circ} \mathrm{C}$ 에서 3 시간 동안 추출하였다. 추출수율 은 $0.1 \%$ pectinase구와 cellulase:pectinase가 유사하였지만, 다양한 성분의 세포벽 분해를 위하여 cellulase:pectinase 혼 합 첨가 처리구를 선택하였다. 추출온도, 추출시간, 추출 교반속도별 최적조건 확립 실험에서는 cellulase:pectinase 혼합 효소 $0.1 \%$ 를 첨가하여 실험을 진행하였다.

최적 추출온도 확립을 위하여 온도를 $40,45,50$ 및 $55^{\circ} \mathrm{C}$ 로 달리하여 3시간 추출하여 추출수율을 비교하였다. 최적 추출시간 확립을 위하여 가장 효율이 좋은 온도 $45^{\circ} \mathrm{C}$ 로 고정하고 시간을 $0,2,3,4$ 및 5 시간으로 달리하여 추출하였 으며, 최적 추출 교반속도를 확립하기 위하여 온도는 $45^{\circ} \mathrm{C}$, 추출시간은 3 시간으로 고정시킨 후 추출 교반속도를 0,30 ,
60, 90 및 $120 \mathrm{rpm}$ 으로 달리하여 추출액 중 추출수율, 당도, 산도, 총 페놀 및 유리당 함량을 측정하여 비교하였다.

\section{추출수율}

각 처리구별로 추출한 블루베리 시료를 일정한 압력을 가하여 종이 여과지 $(125 \mathrm{~mm}$, Whatman, Buckinghamshire, $\mathrm{UK}$ )로 여과한 후 무게를 측정하였으며, 총 블루베리 첨가 량에서 잔사 된 블루베리 양을 뺀 값을 총 블루베리 첨가량 으로 나눈 후 100 을 곱하여 추출률을 구하였다.

\section{$\mathrm{pH}$ 및 당도}

$\mathrm{pH}$ 측정은 $\mathrm{pH}$ meter(pH/Ion 510, Oakton Instruments, IL, USA)를 이용하여 측정하였으며, 당도는 굴절당도계 (Master Refractometer, Atago, Tokyo, Japan)를 사용하여 측 정하였다.

\section{총 페놀 함량}

총 페놀 함량은 Folin-Denis의 방법(19)을 변형하여 측정 하였다. 각 블루베리 추출 시료 용액 $1 \mathrm{~mL}$ 에 Folin \& Ciocalteau's phenol reagent $1 \mathrm{~mL}$ 를 가하여 실온에서 3분간 반응시켰다. 반응용액에 $10 \% \mathrm{Na}_{2} \mathrm{CO}_{3}$ 용액 $1 \mathrm{~mL}$ 를 가한 다음 이 혼합 용액을 1 시간 동안 정치한 후 UV/VIS 분광분 석기(UV-1280, Shimadzu Co., Ltd., Tokyo, Japan)를 사용하 여 $700 \mathrm{~nm}$ 에서 흡광도를 측정하였다. 측정된 흡광도는 갈 릭산(gallic acid)을 이용하여 작성한 표준곡선으로부터 총 페놀화합물 함량을 구하였다.

\section{유리당 함량}

유리당 함량은 Jeong 등(20)의 방법을 응용하여 분석하였 다. 파쇄 한 블루베리 $10 \mathrm{~g}$ 에 $80 \%$ 에탄올 $200 \mathrm{~mL}$ 를 가하여 수옥 상에서 3시간 환류 냉각 추출한 다음 여과하였다. 이 추출조작을 3 회 반복하여 모은 여액을 감압.농축하여 용매 성분을 제거한 후 증류수 $20 \mathrm{~mL}$ 에 녹여 시료 용액으로 사용하였다. 블루베리 추출액의 유리당 함량 분석은 종이 여과지로 여과하여 찌꺼기를 제거한 후 시료액으로 사용하 였다. 증류수와 $100 \%$ 메탄올(LiChrosolv, Merch-Millipore, Darmstadt, Germany)로 활성 시킨 Sep-Pak 카트리지 $\left(\mathrm{C}_{18}\right.$ cartridge, Waters Co., Milford, MA, USA)에 시료액 $5 \mathrm{~mL}$ 를 통과시켜 불순물을 제거하였다. 처음 흘러나온 유출액 3 $\mathrm{mL}$ 는 버리고, 나머지 $2 \mathrm{~mL}$ 를 취하여 멤브레인 필터(0.45 $\mu \mathrm{m}$, Sartorius Stedim Biotech, Goettingen, Germany)로 여과 한 후 HPLC(Waters 2695 separation module, Waters Co.)를 이용하여 분석하였다. 사용된 칼럼(column)은 Unison UK-Amino(150 $\times 4.6$ mm, IMTAKT Co., Tokyo, Japan), 용매 는 $80 \%$ 아세토니트릴(Acetonitrile, LiChrosolv, MerchMillipore), 유속은 $1.0 \mathrm{~mL} / \mathrm{min}$, 검출기는 reactive index detector(RID)를 사용하여 분석하였다. 


\section{통계처리}

실험결과는 SAS 9.1 version을 이용하여 각 시료의 평균 과 표준편차를 계산하였고, 분산분석(ANOVA)과 Duncan's multiple range test을 실시하여 시료 간의 유의차를 검정하 였다( $\mathrm{p}=0.05)$.

\section{결과 및 고찰}

\section{블루베리 추출 최적 효소}

Cellulase, pectinase, cellulase:pectinase(1:1) 혼합 효소를 $0.05,0.1,0.15$ 및 $0.2 \%$ 첨가하여 얻은 블루베리 추출액 중 추출수율, 당도 및 $\mathrm{pH}$ 를 측정한 결과는 Table 1 과 같다. 추출수율은 pectinase 효소를 $0.05,0.1,0.15,0.2 \%$ 처리하였 을 때, 각각 $87.06,87.93,87.49,87.81 \%$ 의 결과를 보였으며, cellulase 효소를 $0.05,0.1,0.15,0.2 \%$ 처리하였을 때, 각각 $85.94,86.18,85.72,86.55 \%$ 로 나타났다. Cellulase:pectinase (1:1) 혼합하여 $0.05,0.1,0.15,0.2 \%$ 처리구에서 각각 86.84 , $87.77,87.25,88.14 \%$ 로 나타나, cellulase 및 pectinase 단독 효소로 처리한 구보다 추출수율이 우수하였다. Pectinase와 cellulase 단독으로 처리하여 얻은 블루베리 추출액의 수율 은 각각 87.06-87.93\%와 85.72-86.55\%로 효소를 처리하지 않은 대조구 $85.02 \%$ 보다 높은 값의 범위를 나타내었다. 효소 처리구에서 대조구 보다 추출수율이 우수하게 나타난 결과는 cellulase와 pectinase 효소는 추출 시 식물 세포벽 및 펙틴을 분해하는 데 중요한 인자로 알려져 있으므로, 블루베리에 이들 효소를 첨가하여 추출하는 동안 cellulase 는 세포벽을 분해하여 수율을 향상시키고, pectinase는 과즙 내 펙틴을 분해하여 수율을 증가시킨 결과로 사료된다. 시 료들의 당도는 $1.10-1.23{ }^{\circ} \mathrm{Brix}$ 의 범위로 유의적인 차이는 없었으나 cellulase:pectinase 혼합 효소의 첨가량이 많아질 수록 점점 상승하는 경향을 보였다. $\mathrm{pH}$ 는 모든 처리구에서 3.19-3.28의 범위로 효소처리에 의한 영향이 거의 없었다. 블루베리 추출액의 $\mathrm{pH}$ 는 각종 유기산 및 다양한 성분 물질 들에 의하여 3.5-4.5라고 보고되었다(21). Yoon 등(22)의 블루베리 착즙액의 $\mathrm{pH}$ 는 3.08 로 보고되어, 본 연구 결과와 유사한 값을 보였으나, Song 등(23)의 연구에서는 블루베리 착즙액 $\mathrm{pH}$ 가 4.35 로 보고되었다. 블루베리 추출액의 $\mathrm{pH}$ 의 차이는 블루베리의 품종과 추출방법 등의 차이 때문으로 사료된다. 최적 추출효소 처리구 선정을 위하여 가장 중요 한 인자는 추출수율이므로, cellulase:pectinase(1:1) 처리구 결과 중 효소를 $0.1 \%$ 처리구가 $87.77 \%, 0.2 \%$ 첨가한 구의 $88.14 \%$ 수율로 나타났으나, 결과 값은 유의적인 차이가 없었다. 경제적인 면을 고려하여 효소량 $0.1 \%$ 처리구를 선택하였다.
Table 1 . Extraction efficiency rate (\%), acidity $(\mathrm{pH})$ and sugar contents ( $\left.{ }^{\circ} \mathrm{Brix}\right)$ of blueberry were summarized based on different enzymes and its ratio

\begin{tabular}{ccccc}
\hline & $\begin{array}{c}\text { Enzyme ratio } \\
(\%)^{1)}\end{array}$ & $\begin{array}{c}\text { Extraction rate } \\
(\%)\end{array}$ & ${ }^{\circ}$ Brix & $\mathrm{pH}$ \\
\hline Control & 0.00 & $85.02 \pm 0.02^{\mathrm{i} 2)}$ & $1.13 \pm 0.06^{\mathrm{bc}}$ & $3.27 \pm 0.01^{\mathrm{a}}$ \\
\hline \multirow{5}{*}{ pectinase } & 0.05 & $87.06 \pm 0.06^{\mathrm{cd}}$ & $1.17 \pm 0.06^{\mathrm{abc}}$ & $3.24 \pm 0.01^{\mathrm{b}}$ \\
& 0.10 & $87.93 \pm 0.12^{\mathrm{ab}}$ & $1.10 \pm 0.00^{\mathrm{c}}$ & $3.28 \pm 0.01^{\mathrm{a}}$ \\
& 0.15 & $87.49 \pm 0.10^{\mathrm{bc}}$ & $1.17 \pm 0.06^{\mathrm{abc}}$ & $3.22 \pm 0.01^{\mathrm{cd}}$ \\
& 0.20 & $87.81 \pm 0.10^{\mathrm{ab}}$ & $1.13 \pm 0.06^{\mathrm{bc}}$ & $3.20 \pm 0.01^{\mathrm{efg}}$ \\
\hline \multirow{4}{*}{ cellulase } & 0.05 & $85.94 \pm 0.16^{\mathrm{gh}}$ & $1.20 \pm 0.00^{\mathrm{ab}}$ & $3.22 \pm 0.01^{\mathrm{cd}}$ \\
& 0.10 & $86.18 \pm 0.18^{\mathrm{fg}}$ & $1.20 \pm 0.00^{\mathrm{ab}}$ & $3.23 \pm 0.00^{\mathrm{bc}}$ \\
& 0.15 & $85.72 \pm 0.38^{\mathrm{h}}$ & $1.23 \pm 0.06^{\mathrm{a}}$ & $3.22 \pm 0.01^{\mathrm{cde}}$ \\
& 0.20 & $86.55 \pm 0.51^{\mathrm{ef}}$ & $1.20 \pm 0.00^{\mathrm{ab}}$ & $3.22 \pm 0.01^{\mathrm{cd}}$ \\
\hline \multirow{4}{*}{ cellulase: } & 0.05 & $86.84 \pm 0.31^{\mathrm{de}}$ & $1.10 \pm 0.00^{\mathrm{c}}$ & $3.24 \pm 0.01^{\mathrm{b}}$ \\
pectinase $(1: 1)$ & 0.10 & $87.77 \pm 0.30^{\mathrm{ab}}$ & $1.17 \pm 0.06^{\mathrm{abc}}$ & $3.21 \pm 0.01^{\text {def }}$ \\
& 0.15 & $87.25 \pm 0.31^{\mathrm{cd}}$ & $1.20 \pm 0.00^{\mathrm{ab}}$ & $3.19 \pm 0.01^{\mathrm{g}}$ \\
& 0.20 & $88.14 \pm 0.32^{\mathrm{a}}$ & $1.23 \pm 0.06^{\mathrm{a}}$ & $3.20 \pm 0.01^{\mathrm{fg}}$ \\
\hline
\end{tabular}

${ }^{1)}$ Enzyme ratio (\%) represents $67.5 \mathrm{U}$ for $0.05 \%, 270 \mathrm{U}$ for $0.10 \%, 607.5 \mathrm{U}$ for $0.15 \%, 1,080 \mathrm{U}$ for $0.20 \%$ in pectinase, while $60 \mathrm{U}$ for $0.05 \%, 240 \mathrm{U}$ for $0.10 \%$, $540 \mathrm{U}$ for $0.15 \%, 960 \mathrm{U}$ for $0.20 \%$ in cellulase. $63.75 \mathrm{U}$ for $0.05 \%, 255 \mathrm{U}$ for $0.10 \%, 573.75 \mathrm{U}$ for $0.15 \%, 1,020 \mathrm{U}$ for $0.20 \%$ in cellulase:pectinase (1:1). Each treatment was incubated with enzymes for $3 \mathrm{~h}$ at $45^{\circ} \mathrm{C}$.

${ }^{2)}$ Values represent the mean $\pm \mathrm{SD}(\mathrm{n}=3)$ and different letters indicate significant differences $(\mathrm{p}<0.05)$.

\section{블루베리 추출 최적 온도}

블루베리 추출 최적 추출온도를 확립하기 위하여 cellulase:pectinase(1:1) $0.1 \%$ 처리하고 $40,45,50,55^{\circ} \mathrm{C}$ 온도 에서 블루베리 추출액의 추출수율, 당도 및 $\mathrm{pH}$ 를 측정한 결과는 Table 2 와 같다. $40,45,50,55^{\circ} \mathrm{C}$ 온도 범위에서의 추출수율은 각각 $87.62,87.91,87.58,87.65 \%$ 로 조사되었으 며, 이 결과 중 $45^{\circ} \mathrm{C}$ 에서 $87.91 \%$ 로 가장 높은 추출수율을 보였다. 당도는 $50^{\circ} \mathrm{C}$ 에서 가장 높은 $1.30{ }^{\circ} \mathrm{Brix}$ 값을 보였으 나 처리 간 유의적인 차이는 없었다. $\mathrm{pH}$ 는 3.17-3.23의 범위 로 온도에 의한 영향이 거의 없었다. 블루베리 추출 최적 온도는 추출수율이 가장 우수한 결과를 나타낸 $45^{\circ} \mathrm{C}$ 로 선정 하였다.

\section{블루베리 추출 최적 시간}

블루베리 추출 최적 추출시간을 확립하기 위하여 블루베 리에 cellulase:pectinase(1:1) 혼합 효소를 $0.1 \%$ 첨가하고 $45^{\circ} \mathrm{C}$ 온도에서 $0,2,3,4,5$ 시간 추출한 추출액의 추출수율, 당도 및 $\mathrm{pH}$ 를 측정한 결과는 Table 2 와 같다. $0,2,3,4$, 5 시간에서 블루베리 추출수율은 각각 $85.21,86.82,87.88$, $87.39,86.68 \%$ 로 조사되었으며, 3시간 및 4시간 추출 시 가장 우수한 결과를 보였다. 이 결과는 시간이 지날수록 추출성분의 농도가 증가하지만 유의적인 차이가 없으므로 3 시간 이상 추출할 필요가 없을 것으로 판단되었다. 당도는 
1.10-1.27 ${ }^{\circ} \mathrm{Brix}$ 값을 보였으며, 통계적으로 유의차가 없었 다. $\mathrm{pH}$ 는 3.20-3.23의 범위로 시간에 의한 영향이 거의 없었 다. 최적 추출시간은 추출수율이 가장 우수한 3 시간 추출하 는 것이 가장 적당할 것으로 사료되었다.

Table 2. Analysis of extraction efficient rate (\%), sugar contents $\left({ }^{\circ} \mathrm{Brix}\right)$, and acidity $(\mathrm{pH})$ of blueberry extract according to different extraction temperatures, extraction times, and shaking speeds after enzyme treatment

\begin{tabular}{cccc}
\hline \multirow{2}{*}{ Variation $^{\mathrm{l})}$} & \multicolumn{3}{c}{ Conditions } \\
\cline { 2 - 4 } & $\begin{array}{c}\text { Extraction rate } \\
(\%)\end{array}$ & ${ }^{\circ}$ Brix & $\mathrm{pH}$ \\
\hline${\text { Temperature }\left({ }^{\circ} \mathrm{C}\right)}$ & & \\
40 & $87.62 \pm 0.15^{\mathrm{cb} 2)}$ & $1.20 \pm 0.06^{\mathrm{bc}}$ & $3.17 \pm 0.02^{\mathrm{b}}$ \\
45 & $87.91 \pm 0.05^{\mathrm{a}}$ & $1.20 \pm 0.00^{\mathrm{ab}}$ & $3.23 \pm 0.02^{\mathrm{a}}$ \\
50 & $87.58 \pm 0.11^{\mathrm{c}}$ & $1.30 \pm 0.06^{\mathrm{a}}$ & $3.19 \pm 0.00^{\mathrm{b}}$ \\
55 & $87.65 \pm 0.05^{\mathrm{b}}$ & $1.10 \pm 0.00^{\mathrm{c}}$ & $3.23 \pm 0.01^{\mathrm{a}}$ \\
\hline Time (h) & & & \\
0 & $85.21 \pm 0.05^{\mathrm{c}}$ & $1.20 \pm 0.00^{\mathrm{b}}$ & $3.23 \pm 0.00^{\mathrm{a}}$ \\
2 & $86.82 \pm 0.28^{\mathrm{ab}}$ & $1.20 \pm 0.00^{\mathrm{b}}$ & $3.22 \pm 0.00^{\mathrm{a}}$ \\
3 & $87.88 \pm 0.10^{\mathrm{a}}$ & $1.20 \pm 0.00^{\mathrm{b}}$ & $3.20 \pm 0.01^{\mathrm{b}}$ \\
4 & $87.39 \pm 0.05^{\mathrm{a}}$ & $1.27 \pm 0.06^{\mathrm{a}}$ & $3.20 \pm 0.01^{\mathrm{b}}$ \\
5 & $86.68 \pm 0.05^{\mathrm{b}}$ & $1.10 \pm 0.00^{\mathrm{c}}$ & $3.20 \pm 0.02^{\mathrm{b}}$ \\
\hline Agitation rate (rpm) & & & \\
0 & $87.51 \pm 0.05^{\mathrm{d}}$ & $1.17 \pm 0.06^{\mathrm{a}}$ & $3.21 \pm 0.01^{\mathrm{c}}$ \\
30 & $87.92 \pm 0.10^{\mathrm{cd}}$ & $1.17 \pm 0.06^{\mathrm{a}}$ & $3.22 \pm 0.01^{\mathrm{b}}$ \\
60 & $88.48 \pm 0.79^{\mathrm{bc}}$ & $1.20 \pm 0.00^{\mathrm{a}}$ & $3.19 \pm 0.00^{\mathrm{d}}$ \\
90 & $89.19 \pm 0.00^{\mathrm{a}}$ & $1.20 \pm 0.00^{\mathrm{a}}$ & $3.22 \pm 0.01^{\mathrm{b}}$ \\
120 & $88.92 \pm 0.05^{\mathrm{ab}}$ & $1.07 \pm 0.06^{\mathrm{b}}$ & $3.25 \pm 0.01^{\mathrm{a}}$ \\
\hline
\end{tabular}

${ }^{11} 0.1 \%$ cellulase:pectinase mix $(1: 1)$ was used as a fixed factor for temperature variation and treated for $3 \mathrm{~h}$ at $45^{\circ} \mathrm{C}$. $0.1 \%$ cellulase:pectinase mix $(1: 1)$ and $45^{\circ} \mathrm{C}$ were fixed factors for extraction time variation. For agitation rate, $0.1 \%$ cellulase:pectinase mix (1:1) were treated at $45^{\circ} \mathrm{C}$ for $3 \mathrm{~h}$

${ }^{2)}$ Values represent the mean $\pm \mathrm{SD}(\mathrm{n}=3)$ and different letters indicate significant differences $(\mathrm{p}<0.05)$.

\section{블루베리 추출 최적 교반속도}

블루베리 추출 최적 교반속도 조건을 확립하기 위하여 블루베리에 cellulase:pectinase(1:1) 혼합 효소를 $0.1 \%$ 첨가 하고 $45^{\circ} \mathrm{C}, 3$ 시간 동안 추출하면서 교반 속도를 $0,30,60$, $90,120 \mathrm{rpm}$ 으로 달리하여 추출액의 추출수율, 당도 및 $\mathrm{pH}$ 를 측정한 결과는 Table 2 와 같다. $0,30,60,90,120 \mathrm{rpm}$ 에서 추출수율은 각각 $87.51,87.92 .88 .48,89.19,88.92 \%$ 의 결과 였으며, $90 \mathrm{rpm}$ 에서 $89.19 \%$ 로 가장 높은 값을 보였다. 0 에 서 $90 \mathrm{rpm}$ 의 교반속도까지는 속도가 증가할수록 추출수율 이 증가하였으나, $120 \mathrm{rpm}$ 까지 속도를 증가시켜도 추출수 율에 효과가 없는 결과를 보였다. 최적 교반속도는 추출수 율이 가장 우수한 $90 \mathrm{rpm}$ 으로 선정하였다. 당도는 $1.07-$ $1.20{ }^{\circ} \mathrm{Brix}$ 값을 보였으며, $\mathrm{pH}$ 는 3.19-3.25의 범위로 교반속
도에 의한 영향이 거의 없었다.

\section{총 페놀함량}

페놀성 화합물 안토시아닌(anthocyanin), 카테킨(catechin), 클로로제닉산(chlorogenic acid) 등은 식물계에 널리 분포되 어 있는 2 차 대사산물 중 하나로 다양한 구조와 분자량을 가진다. 페놀성 화합물의 페놀 수산기 $(-\mathrm{OH})$ 는 단백질 등과 결합하는 성질을 가지며 항산화 효소와 함께 연속적인 짝반 응을 통해 간접적으로 자유전자를 소거하거나, 자유전자와 함께 공명안정화된 페녹시 전자(resonance-stabilized phenoxy radical)를 형성하여 직접 자유기를 제거한다. 이는 항산화, 항암 및 항균효과 등의 생리활성을 가지는 것으로 알려졌다 $(24,25)$. 추출조건을 달리한 블루베리의 총 페놀 함량은 Fig. 1 과 2 에 나타냈다. 총 페놀함량 분석결과 효소를 첨가하지 않은 군에서는 $16.8 \mathrm{mg} / \mathrm{g}$ 를 나타내었고, cellulase 효소를 첨가한 군에서는 $15.41-18.1 \mathrm{mg} / \mathrm{g}$, pectinase 효소를 첨가한 군에서는 17.51-18.62 mg/g, cellulase:pectinase 혼합 처리군 에서는 $15.23-17.81 \mathrm{mg} / \mathrm{g}$ 로 유의적인 차이는 없었다. cellulase:pectinase(1:1) 혼합 효소 $0.1 \%$ 사용하며 온도를 $40-55^{\circ} \mathrm{C}$ 로 처리한 구에서는 $17.23-18.90 \mathrm{mg} / \mathrm{g}$ 의 결과를 보 였으나, 유의적인 차이가 없었다. 추출시간에 따른 총 폴리 페놀 함량은 3 시간 추출 시 $18.06 \mathrm{mg} / \mathrm{g}$ 으로 가장 우수한 결과를 보여서 추출 수율과 유사한 결과를 보였다. 교반속 도에 따른 함량은 $16.51-19.14 \mathrm{mg} / \mathrm{g}$ 의 범위를 나타내었다. $120 \mathrm{rpm}$ 속도에서 $19.14 \mathrm{mg} / \mathrm{g}$ 의 함량으로 가장 높은 결과를 보였으나, 0-90 rpm 속도에서는 유의적인 차이가 없었다.

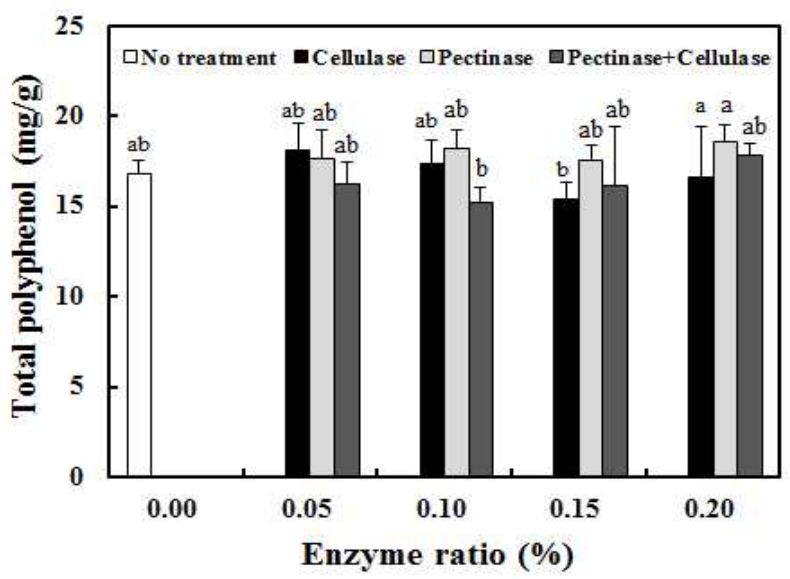

Fig. 1. Total polyphenol content of blueberry extract according to different enzyme treatments and its ratio. Cellulase, pectinase, or cellulase:pectinase $(1: 1) \mathrm{mix}$ were treated for $3 \mathrm{~h}$ at $45^{\circ} \mathrm{C}$.

Cellulase, Enzyme ratio (\%) represents $60 \mathrm{U}$ for $0.05 \%, 240 \mathrm{U}$ for $0.10 \%, 540 \mathrm{U}$ for $0.15 \%, 960 \mathrm{U}$ for $0.20 \%$ in cellulase

Pectinase, while $67.5 \mathrm{U}$ for $0.05 \%, 270 \mathrm{U}$ for $0.10 \%, 607.5 \mathrm{U}$ for $0.15 \%, 1,080 \mathrm{U}$ for $0.20 \%$ in pectinase.

Cellulas+Pectinase, $63.75 \mathrm{U}$ for $0.05 \%, 255 \mathrm{U}$ for $0.10 \%, 573.75 \mathrm{U}$ for $0.15 \%, 1,020$ $\mathrm{U}$ for $0.20 \%$ in cellulase:pectinase (1:1). Different letters indicate significant differences $(\mathrm{p}<0.05)$. 
(A)

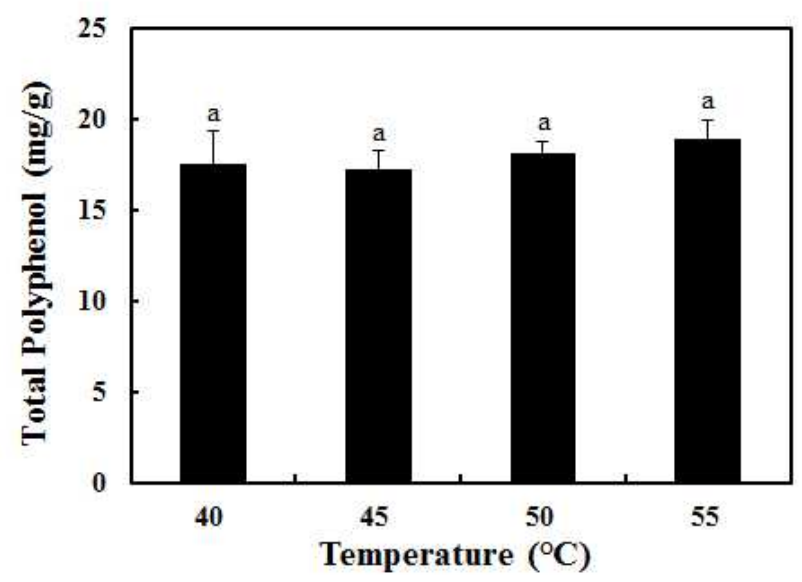

(B)

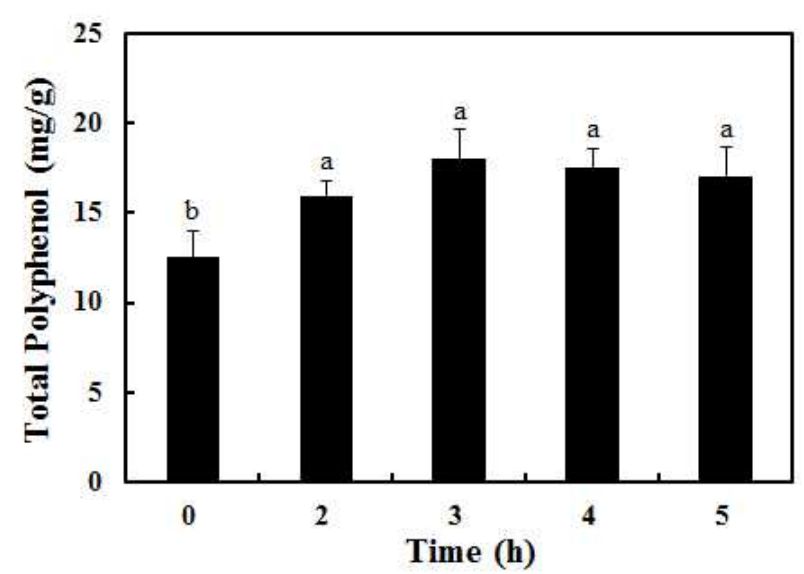

(C)

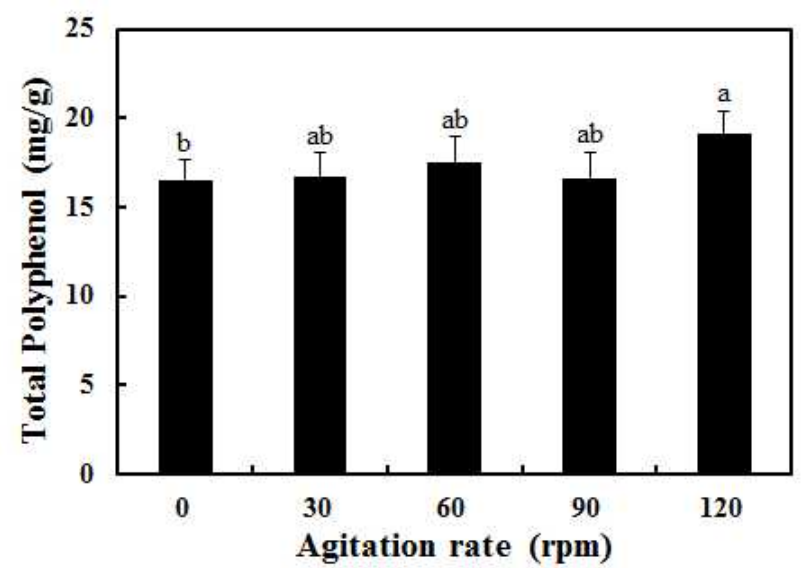

Fig. 2. Total polyphenol contents of blueberry extract based on temperature (A), time (B), and agitation rate (C) after fixing the enzyme and its amount.

Enzyme incubation temperature was $40,45,50$, or $55^{\circ} \mathrm{C}$. Extraction time was 0,2 , 3,4 or $5 \mathrm{~h}$. Shaking speed was $0,30,60,90,120 \mathrm{rpm}$. $0.1 \%$ mix enzymes were treated for $3 \mathrm{~h}$ at $45^{\circ} \mathrm{C}$

Values represent the mean $\pm S D(n=3)$. Different letters indicate significant differences $(\mathrm{p}<0.05)$.
Jeong 등(1)은 블루베리 추출액에서 총 폴리페놀 함량을 측정한 결과, $9.02 \mathrm{mg} / \mathrm{g}$ 의 총 페놀화합물 함량을 보였다고 보고하였다. 본 연구와 차이가 나는 것은 실험에 사용한 블루베리의 원산지, 품종뿐 아니라 실험 시 원료의 혼합 여부 등에서 비롯된 것으로 추측된다.

\section{유리당 함량}

본 시험에 사용된 블루베리 원료의 유리당 함량은 과당 $2.53 \%$ 와 포도당 $2.40 \%$ 이었다. Song 등(23)은 블루베리 유 리당 함량을 분석한 결과 과당 $2.99 \%$, 포도당 $2.81 \%$ 를 함유 하고 있는 것으로 보고하였는데, 이는 본 연구의 실험결과 와 유사한 결과를 나타내었다. Park 등(26)에 따르면 블루베 리에 포도당, 과당, 자당과 맥아당이 검출되었다고 보고하

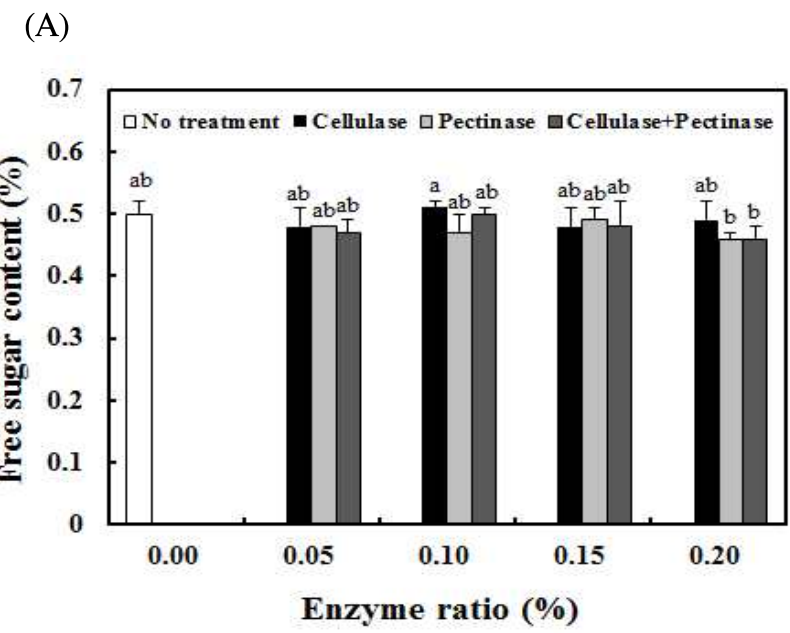

(B)

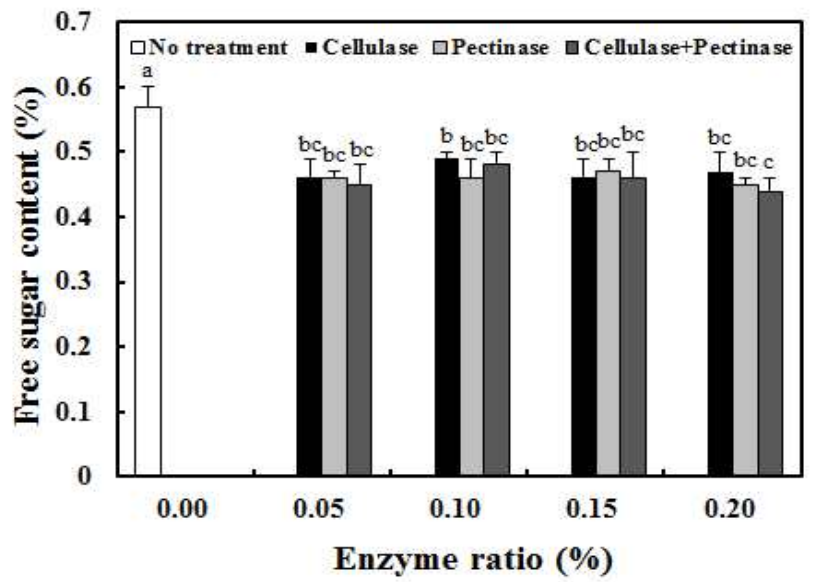

Fig. 3. Free sugar glucose (A) and fructose (B) contents of blueberry extract according to different enzyme treatments.

Cellulase, Enzyme ratio (\%) represents $60 \mathrm{U}$ for $0.05 \%, 240 \mathrm{U}$ for $0.10 \%, 540 \mathrm{U}$ for $0.15 \%, 960 \mathrm{U}$ for $0.20 \%$ in cellulase.

Pectinase, while $67.5 \mathrm{U}$ for $0.05 \%, 270 \mathrm{U}$ for $0.10 \%, 607.5 \mathrm{U}$ for $0.15 \%, 1,080 \mathrm{U}$ for $0.20 \%$ in pectinase.

Cellulase+Pectinase, $63.75 \mathrm{U}$ for $0.05 \%, 255 \mathrm{U}$ for $0.10 \%, 573.75 \mathrm{U}$ for $0.15 \%, 1,020$

$\mathrm{U}$ for $0.20 \%$ in cellulase:pectinase(1:1).

Different letters indicate significant differences $(p<0.05)$ 
(A)

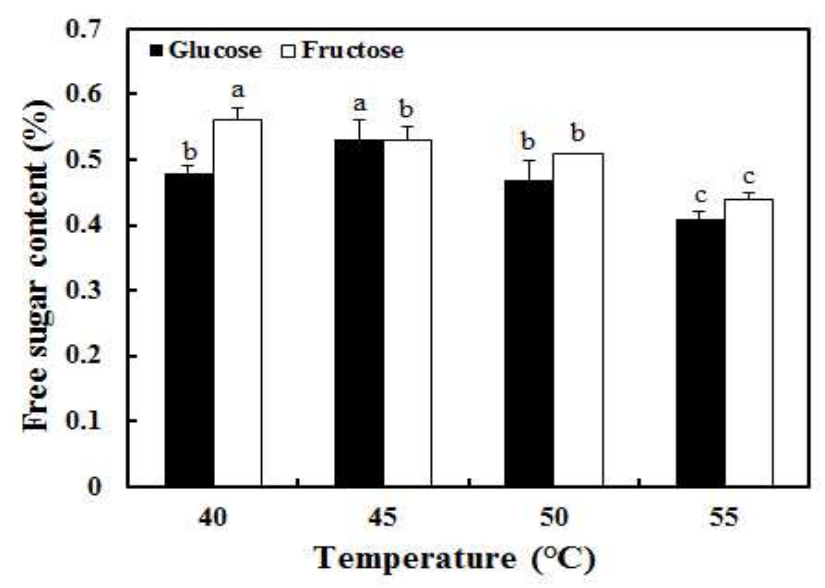

(B)

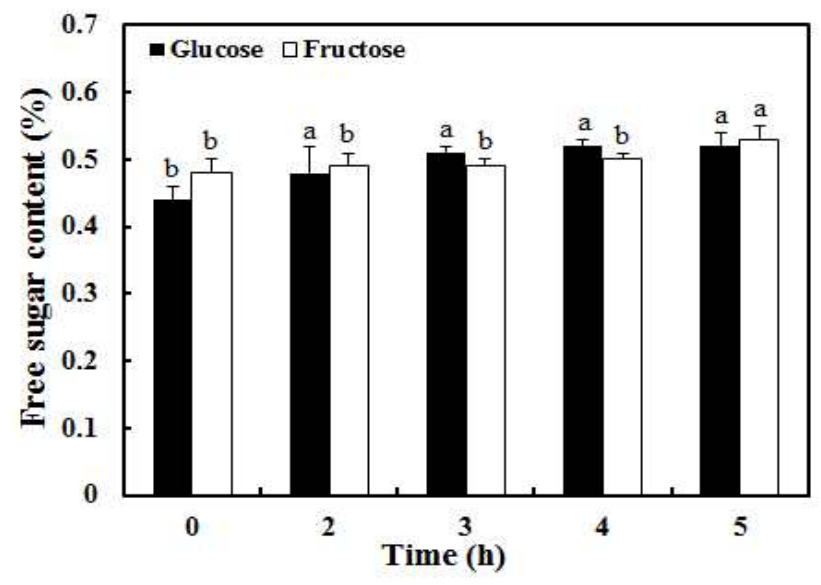

(C)

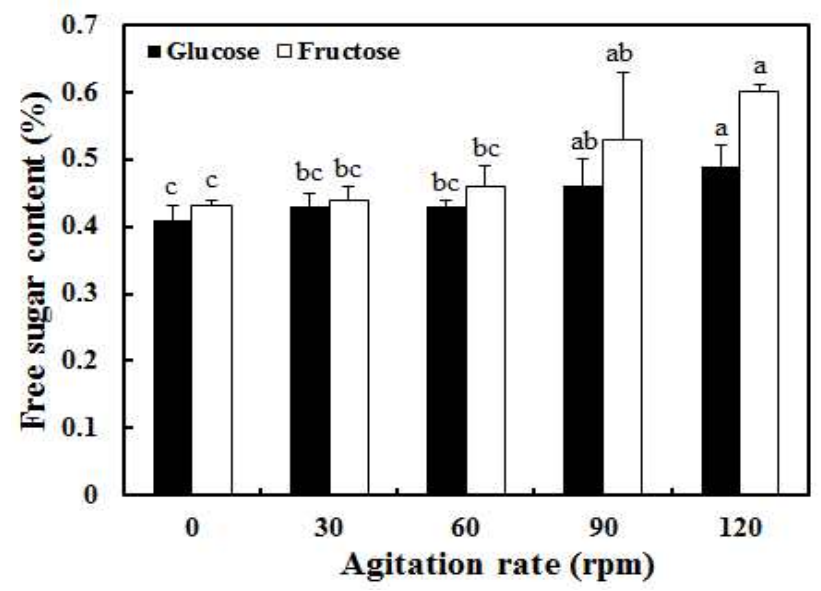

Fig. 4. Glucose and fructose contents of blueberry crude extract according to temperature (A), time (B), and agitation rate (C) after fixing the enzyme and its amount.

Enzyme incubation temperature was $40,45,50$, or $55^{\circ} \mathrm{C}$. Extraction time was 0,2 , 3,4 or $5 \mathrm{~h}$. Shaking speed was $0,30,60,90,120 \mathrm{rpm}$. $0.1 \%$ mix enzymes were treated for $3 \mathrm{~h}$ at $45^{\circ} \mathrm{C}$.

Values represent the mean $\pm S D(n=3)$. Different letters indicate significant differences $(\mathrm{p}<0.05)$.
여 본 연구 결과와 다소 차이가 보였으나, Lee 등(27)은 블루베리에서 과당과 포도당이 검출되었다고 보고하여 본 연구와 유사한 결과를 보였다. 블루베리에 효소 처리, 온도, 시간, 교반속도 조건을 달리하여 제조한 블루베리 추출액 중의 유리당 함량을 분석한 결과를 Fig. 3과 4에 나타내었 다. 유리당 함량을 측정한 결과 모든 시료에서 과당과 포도 당이 검출되었다. 효소 무첨가 추출구인 대조구에서는 과 당 $0.57 \%$, 포도당 $0.5 \%$, cellulase 처리구에서는 과당 0.46-0.49\%, 포도당 0.48-0.51\%, pectinase 처리구는 과당 0.45-0.47\%, 포도당 0.46-0.49\%, cellulase:pectinase (1:1) 혼 합 효소 처리구는 과당 $0.44-0.48 \%$, 포도당 0.46-0.5\%로 조사되었으나, 이들 결과 수치들은 유의적인 차이는 없어 서 효소의 종류 및 함량에 따라서 유리당 함량에 영향을 미치지 않은 것으로 판단된다.

추출 온도를 달리한 유리당 함량 중 과당은 $40^{\circ} \mathrm{C}$, 포도당 은 $45^{\circ} \mathrm{C}$ 에서 높은 함량을 보였다. 유리당 함량은 효소의 최적 추출수율이 가장 우수한 온도인 $45^{\circ} \mathrm{C}$ 에서 비교적 높은 결과를 보였다. 추출시간에 따른 함량의 차이는 과당은 0 시 간 보다 2-5시간 추출 시 높은 함량이었으며, 포도당은 5시 간 추출 시 가장 높은 결과를 보였다. 교반 속도에 따른 과당 및 포도당의 함량 모두 90 및 $120 \mathrm{rpm}$ 에서 가장 높은 함량으로 조사되었다. 유리당 함량은 $90 \mathrm{rpm}$ 에서 추출수율 이 가장 우수하였던 결과와 유사한 경향을 나타냈다.

\section{블루베리 최적 추출조건}

본 연구에서는 블루베리를 저온에서 최적 추출 조건을 확립하고자 효소 종류 및 첨가량, 최적 온도, 최적 추출 시간, 최적 교반 속도를 비교하였다. 블루베리 음료 제조를 위한 최적 효소 선정 시 추출수율이 가장 우수하고 세포벽 의 다양한 성분을 분해할 수 있는 cellulase와 pectinase를 $1: 1(\mathrm{v} / \mathrm{v})$ 혼합구를 선정하였으며, 경제적인 면을 고려하여 최소 첨가로 추출수율이 우수한 $0.1 \%$ 첨가량으로 선정하였 다. 최적 추출 온도는 $45^{\circ} \mathrm{C}$, 추출 시간은 3 시간, 교반 속도는 $90 \mathrm{rpm}$ 에서 가장 우수한 결과를 보였다. 이상의 결과를 고려하여 블루베리 추출 최적 조건은 cellulase와 pectinase 를 $1: 1(\mathrm{v} / \mathrm{v})$ 혼합효소 $0.1 \%$ 를 사용하여 $45^{\circ} \mathrm{C}$ 에서 3 시간 동안 $90 \mathrm{rpm}$ 속도로 조사되었다. 본 연구결과를 바탕으로 블루베 리에 효소처리를 하여 추출수율을 증가시키고 국내산 생 과형 블루베리 음료 생산을 위한 자료로 활용할 수 있을 것이다.

\section{요 약}

본 연구에서는 저온추출 뿐만 아니라 효소처리를 이용 하여 생과형 블루베리 과일음료생산을 위한 최적의 방법을 확립하고자 하였다. 생리학적 기능성물질 추출 시 열에 의 
한 영양손실을 막기 위해 저온을 사용하였다. 또한 다양한 효소처리를 이용하여 혼탁 방지 및 추출수율 향상을 위한 최적의 추출조건을 확립하고자 하였다. 블루베리를 cellulase, pectinase 및 cellulase:pectinase(1:1) 혼합 효소와 효소 처리 량, 추출온도, 추출시간, 추출 교반속도 등을 고려한 다양한 조건으로 추출하였을 때, 가장 우수한 추출 조건을 조사하 였다. cellulase로 처리할 경우, 추출률이 85.72-86.55\%, pectinase 처리구는 87.06-87.93\%, cellulase:pectinase(1:1) 혼합 처리할 경우, 86.84-88.14\%의 추출률을 나타냈다. 추 출 온도는 $45^{\circ} \mathrm{C}$ 에서 $87.91 \pm 0.05 \%$, 3시간 추출 하였을 경우 $87.88 \pm 0.10 \%$, 교반속도는 $90 \mathrm{rpm}$ 에서 가장 높은 추출결과 를 보였다. 블루베리 추출액의 당도 및 $\mathrm{pH}$ 는 추출 조건에 관계없이 모든 처리구에서 통계학적으로 유사한 결과를 보였으나, 총 폴리페놀 함량은 pectinase 처리구에서 18.62 $\mathrm{mg} / \mathrm{g}$ 으로 가장 높은 값을 나타냈다. 유리당 함량은 모든 시료에서 과당과 포도당 두 가지 당류만 검출되었으며 cellulase 효소 $0.10 \%$ 를 처리한 블루베리 추출액의 유리당 함량이 포도당 $0.51 \%$, 과당 $0.49 \%$ 로 가장 높았으나 다른 처리구와 유의적인 차이는 없었다. 블루베리를 이용하여 생과일형 음료 제조를 위한 최적 조건은 cellulase: pectinase(1:1) 혼합효소 $0.1 \%$ 를 첨가하여 $45^{\circ} \mathrm{C}$ 온도에서 $90 \mathrm{rpm}$ 의 교반속도로 조사되었다.

\section{감사의 글}

이 논문은 2015년도 교육부의 재원으로 지원을 받아 수 행된 대구대학교 산학협력 선도대학(LINC) 육성사업의 연 구결과입니다.

\section{References}

1. Jeong CH, Choi SG, Heo HJ (2008) Analysis of nutritional compositions and antioxidative activities of Korean commercial blueberry and raspberry. J Korean Soc Food Sci Nutr, 37, 1375-1381

2. Kim EJ, Choi JY, Yu MR, Kim MY, Lee SH, Lee BH (2012) Total polyphenols, total flavonoid contents, and antioxidant activity of Korean natural and medicinal plants. Korean J Food Sci Technol, 44, 337-342

3. Lee MY, Yoo MS, Whang YJ, Jin YJ, Hong MH, Pyo YH (2012) Vitamin C, total polyphenol, flavonoid contents and antioxidant capacity of several fruit peels. Korean J Food Sci Technol, 44, 540-544

4. Ji JR, Yoo SS (2010) Quality characteristics of cookies with varied concentrations of blueberry powder. J East
Asian Soc Dietary Life, 20, 433-438

5. Lee MH, Lee YT (2006) Bread-making properties of rice flours produced by dry, wet and semi-wet milling. J Korean Soc Food Sci Nutr, 35, 886-890

6. Lee WG, Lee JA (2012) Quality characteristics of yogurt dressing prepared with blueberry juice. Korea J Culinary Research, 18, 255-265

7. Seo SH, Yoo SA, Park SE, Son HS (2014) Effectiveness of yeast nutrients on stuck fermentation of blueberry wine. Korean J Food Sci Technol, 46, 143-147

8. Joo NM, Kim BR, Kim AJ (2012) The optimization of jelly with blueberry juice using response surface methodology. Korean J Food Nutr, 25, 17-25

9. Kim KO, Liu YN, Yoon LN, Park HJ (2014) Comparison of quality characteristics and antioxidative activities of cookies containing blueberry powder and different types of egg yolk. J Korean Soc Food Sci Nutr, 43, 999-1008

10. Korea Food \& Drug Administration (2015) Korean Food Code. Cheongju, Korea, p101-118

11. Lee GD, Kim SK, Lee MH (2005) Quality change of beverage containing muskmelon vinegar and concentrated muskmelon juice during storage. Korean J Food Preserv, $12,223-229$

12. Bae JH, Kim KJ, Kim SM, Lee WJ, Lee SJ (2000) Development of the functional beverage containing the Prunus mume extracts. Korean J Food Sci Technol, 32, 713-719

13. Kang KC, Park JH, Baek SB, Jhin HS, Rhee KS (1992) Optimization of beverage preparation from Schizandra chinensis Baillon by response surface methodology. Korean J Food Sci Technol, 24, 74-81

14. Yang HS, Rho JO (2012) The physiochemical characteristic and descriptive sensory evaluation of the blackberry fruit beverage. Korean J Hum Eco, 21, 363-375

15. Choi WS (2012) Development of functional beverage using yam (Dioscorea opposita Thunb.). Food Industry and Nutrition, 17, 20-22

16. Lee JS, Lee JS (2007) Physiological function and development of beverage from Grifola frondosa. J Korean Soc Food Sci Nutr, 36, 1241-1247

17. Park MH, Kim MJ, Cho WI, Chang PS, Lee JH (2011) Volatile changes in beverages and encapsulated powders containing an Artemisia extract during production and storage. Korean J Food Sci Technol, 43, 271-276

18. Jo YJ, Han JW, Min DL, Lee YE, Choi YJ, Lim SK (2015) Optimization of acetic acid fermentation for 
producing vineger from extract of jujube (Zizyphus jujuba Mill.) fruits. Korean J Food Sci Technol, 47, 711-718

19. Zhang Q, Zhang J, Shen J, Silva A, Dennis DA, Barrow CJ (2006) A simple 96-well microplate method for estimation of total polyphenol content in seaweeds. J Appl Phycol, 18, 445-450

20. Jeong YJ, Seo JH, Lee GD, Lee MH, Yoon SR (2000) Changes in quality characteristics of traditional Kochujang prepared with apple and persimmon during fermentation. J Korean Soc Food Sci Nutr, 29, 575-581

21. Jo HJ, Kim JE, Yu MJ, Lee WH, Song KB, Kim HY, Hwang IG, Yoo SM, Han GJ, Park JT (2014) Effect of freezing temperature on blueberry quality. J Korean Soc Food Sci Nutr, 43, 1906-1912

22. Yoon HH, Chae KS, Son RH, Jung JH (2015) Antioxidant activity and fermentation characteristics of blueberry wine using traditional yeast. J Korean Soc Food Sci Nutr, 44, 840-846

23. Song HN, Park MS, Youn HS, Park SJ, Hogstrand C (2014) Nutritional compositions and antioxidative activities of two blueberry varieties cultivated in South Korea. Korean J Food Preserv, 21, 790-798

24. Lee SM, Yoo YH, Kim KM, Park JJ, Jeong CS, Jhon DY, Jun WJ (2012) Antioxidant activities of native Gwangyang Rubus coreanus Miq.. J Korean Soc Food Sci Nutr, 41, 327-332

25. Jeong SJ, Shim HR, Lee JS, Nam HS, Lee HG (2015) Antioxidant and synergistic activities of fruit and vegetable concentrates. Korean J Food Sci Technol, 47, 240-245

26. Park SJ, Choi YB, Ko JR, Rha YA, Lee HY (2014) Effects of drying methods on the quality and physiological activities of blueberry (Vaccinium ashe1). Korea J Culinary Research, 20, 55-64

27. Lee YC, Lee JH, Kim SD, Chang MS, Jo IS, Kim SJ, Hwang KT, Jo HB, Kim JH (2015) Chemical composition, functional constituents, and antioxidant activities of berry fruits produced in Korea. J Korean Soc Food Sci Nutr, 44, 1295-1303 